Área Abierta. Revista de comunicación audiovisual y publicitaria ISSN: 2530-7592 / ISSNe: 1578-8393

http://dx.doi.org/10.5209/arab.69118

\title{
Canciones para después de una guerra. Una película: dos tiempos ${ }^{1}$
}

\author{
Fernando Benito González García
}

Recibido: 30 de abril de 2020 / Aceptado: 15 de mayo de 2020

Resumen. Este artículo propone estudiar Canciones para después de una guerra en el momento en el que fue concebida y elaborada, antes de la prohibición en 1971 que retrasó su estreno hasta 1977, en unas circunstancias políticas y mediáticas, tanto españolas como internacionales, muy distintas. Se prestará especial atención a la gestación de la película, a su proceso de elaboración y a la propuesta de Basilio Martín Patino de enlazar espectáculo, pensamiento y juego, posicionándose también de manera consciente ante la televisión.

Palabras clave: Basilio Martín Patino; Censura; Collage; Montaje; Proceso; Juego

\section{[en] Song for after a War. A Film: Two Times}

Abstract. This article proposes to study Canciones para después de una guerra at the time when it was conceived and elaborated, before the prohibition in 1971 which delayed its premiere until 1977, in very different political and media circumstances, both Spanish and international. Special attention will be paid to the gestation of the film, to its elaboration process and to Basilio Martín Patino's proposal to link show, thought and game, while also consciously positioning himself in front of the television.

Keywords: Basilio Martín Patino; Censorship; Collage; Editing; Process; Play

Sumario. 1. Introducción. 2. Una posible carrera internacional. 3. El proceso: de la documentación al descubrimiento. 4. Imágenes visuales y sonoras para un espectáculo poético y crítico. 5. Conclusiones. 6. Bibliografía.

Cómo citar. González García, Fernando Benito (2020). Canciones para después de una guerra. Una película, dos tiempos. Área Abierta. Revista de comunicación audiovisual y publicitaria 20 (2), 159175, http://dx.doi.org/10.5209/arab.69118

\footnotetext{
1 Este trabajo se enmarca en el proyecto de investigación "Intermedialidad e institución. Relaciones inter-artísticas: literatura, audiovisual, artes plásticas”, financiado por el Ministerio de Ciencia, Innovación y Universidades, referencia: HAR2017-85392-P.

2 Universidad de Salamanca (España)

E-mail: fergogar@usal.es
} 


\section{Introducción}

Dice Nancy Berthier, refiriéndose a Canciones para después de una guerra (1971), Caudillo (1973) y Queridísimos verdugos (1973) que "si no son películas de la Transición en la medida en que su elaboración se sitúa en el tardofranquismo, son sin lugar a dudas películas de transición en la medida en que abren unas brechas que se irán ensanchando" (Berthier, 2011: 192). Tras cinco años de prohibición, en septiembre de 1976 se produce el "desbloqueo y estreno del ya vetusto Canciones para después de una guerra", según expresión, en 1986, de Julio Pérez Perucha y Vicente Ponce (2011: 226). En este sentido Jorge Nieto Ferrando (2006: 89) escribe que la película se resiente de los importantes cambios que ha sufrido en estos años su contexto de recepción, afirmación con la que no puedo estar más de acuerdo: el título de este trabajo, que habla de una película en dos tiempos, se refiere precisamente a esos contextos tan diferentes.

Cuando finalmente el público español pudo ver Canciones para después de una guerra, en 1976, el éxito fue arrollador. Más de ochocientas mil personas asistieron a las salas (Martín Morán, 2008: 59), y nadie sabe cuántas pudieron comprar el disco que editó CBS en vinilo y en cinta de cassette. El éxito de esta antología musical se extendió a otros países donde había emigración española: en Argentina, el disco fue editado por la casa Impacto, también en 1976. La acogida del público a la película tuvo que ver, evidentemente, con unas canciones que formaban parte de la educación política y sentimental de muchos españoles, tanto residentes en España como emigrados: además, no era fácil encontrar ya muchas de ellas en el mercado. Pero había otros factores en juego. Palmira Vélez Jiménez (2014: 263) afirma: "el éxito no lo explica la nostalgia. Solo unos meses antes, Canciones de nuestra vida tuvo poco más de cien mil espectadores". "Si acaso -sigue- lo explicaría la capacidad de la película para vincular un pasado cerrado, exótico, con el presente". Los temas musicales de Canciones para después de una guerra, como sus imágenes, van desde los años treinta hasta los cincuenta, pero son fundamentalmente de los cuarenta, sugiriendo una etapa cerrada, aunque el tratamiento audiovisual -que Hopewell vincula con la publicidad (1989: 115) y Pérez Millán (2002: 137) llega a comparar con el videoclip- los trae de nuevo a la actualidad.

John Hopewell se extrañaba de que la película hubiera llenado las salas con gente de tendencias políticas incluso contrarias y que en algún caso -en Valencia- parte del público corease el Cara al sol con el brazo levantado y otros respondieran cantando en pasado Se va el caimán -canción que pareció disgustarle mucho en su momento al propio Franco-, y achacase a los primeros una mala comprensión de la ironía que contiene el montaje (Hopewell, 1989: 114). Habría que recordar aquí que ya la comisión de censura, en un primer momento, tras varios visionados y la recomendación de un importante número de modificaciones no solo aprobó la película, sino que le concedió la categoría de Interés Especial. No fue prohibida -se afirma que por el propio presidente del Gobierno, el almirante Carrero Blanco- hasta después de la agria polémica que despertó su candidatura para ser estrenada en el Festival de San Sebastián de 1971, que enfrentó a distintos sectores del propio régimen, representados por los diarios El Alcázar y Arriba (Pastor Martín, 2004: 299-304; Nieto Ferrando, 2006: 73-89).

El atractivo de la película, según Hopewell, radica en tres factores: su refinado sarcasmo -quizás no fácil de reconocer en todo su alcance en un primer visionado-, 
las propias canciones, y el dinamismo de un montaje que "pasa de una escena a otra con cortante rapidez y cambiando las imágenes y la música a distinto ritmo, lo que crea cierta discordancia entre ellas", y subraya la "rapidez vertiginosa del ritmo, en el que es preciso adivinar antes que ver" (Hopewell, 1989: 114-115). Fue, además, una de las primeras películas prohibidas que pudieron verse tras la muerte de Franco, antes incluso de la abolición de la censura. Por otra parte, como quiso pensar el propio Basilio Martín Patino (2017: 114):

La acogida de la película cuando pudo estrenarse nos desfasó. Yo creo que la sociedad española de aquel momento estaba esperando esta escenificación del reencuentro en la llamada transición. Vino a ser otro factor de reencuentro, de abrazo entre gentes de pensamiento contrario. Recuerdo aquella euforia en el vestíbulo del cine de estreno, entre personalidades significadas de ideas hasta entonces incompatibles. Parecía haber llegado al fin ese día largamente esperado. Fue el momento oportuno. Un periódico publicó en la portada que la película estrenaba libertad. Una afirmación un tanto grandilocuente, pero creo que en cierto modo significativa por las circunstancias que la hacían emblemática.

Siguiendo esta argumentación, Palmira Vélez expone:

¿Qué explica el éxito del film y el disco? El clima de "reconciliación nacional" pudo influir, ya que ninguno de los grandes actores sociales de la segunda mitad de los setenta contaba con la fuerza suficiente para hacer un cambio; de modo que las memorias colectivas radicalmente enfrentadas antes se estaban diluyendo; además, a comienzos de la década casi el $70 \%$ de la población no había vivido la guerra, y el relevo generacional acabará agrietando las férreas identidades de antaño (Vélez, 2014. 268).

Habría que pensar que, quizás también, distintos sectores del público vieran en la película en buena medida lo que querían ver, no tanto por lo que ofrecía en su montaje, como por el significado de su prohibición. Finalmente, como propone Vicente Benet, la película "también anunciaba algunos de los procesos psicológicos vividos por la generación protagonista de la Transición en España", que, tras un adoctrinamiento compacto, podía ver en la recuperación crítica, pero también nostálgica de canciones e imágenes, la pervivencia de un respiro, de una modernidad nunca truncada del todo, así como "mitos compartidos con personas queridas, las reminiscencias de momentos singulares que definían un sentimiento de generación", un material espeso que los cambios por venir deberían gestionar (Benet, 2012: 360-362).

En cualquier caso, y a pesar de diatribas minoritarias vinculadas a sectores radicales (Nieto Ferrando, 2006: 91-95), la película ha pasado a la historia como un hito de la Transición. Para Manuel Trenzado, ya desde su estreno, con Canciones para después de una guerra "comienza a consolidarse una tendencia de recuperación de la memoria colectiva e histórica" (Trenzado, 1999: 307). Aunque, como decía Nancy Berthier, no es esta una película de la Transición, su comprensión posterior está vinculada a su prohibición en 1971, y a las necesidades culturales, sociales y políticas que siguieron a la muerte de Franco, que la han fijado a un país y a un momento. Sin negar la importancia política de la película, su oportunidad, su influencia a partir de 1976, y afirmando a la vez la pertinencia de muchos de los análisis y estudios que se 
le han dedicado y que iré citando en este trabajo, me gustaría profundizar en el alcance potencial, intelectual y estético, de Canciones para después de una guerra en el contexto nacional e internacional del momento en el que fue gestada y terminada (1969-1971).

\section{Una posible carrera internacional}

George Cukor, que estaba en España rodando Viajes con mi tía (Travels with my aunt, 1972), de alguna manera consiguió ver la película y la solicitó para llevarla a un festival en Estados Unidos (Bellido, 1996: 214). En un informe conservado en el Archivo General de la Administración - caja 36/05045- enviado por Manuel Arroyo Stephens el dieciocho de mayo de 1976 a la Dirección General de Cinematografía, del Ministerio de Información y Turismo, "para ayudar a solventar viejos escollos administrativos", se precisa más. Cuando George Cukor y King Vidor solicitaron, en octubre de 1971 la película para exhibirla en la International Film Exposition de Hollywood -en realidad de Los Ángeles-, se les informó desde la Administración de que tal película "no existía". Se trataba de la primera edición de aquel festival, en cuya organización participaba Cukor, y donde aquel año, aparte de una importante selección de clásicos norteamericanos, se estrenó La última película (The Last Picture Show), de Bogdanovich, y pudieron verse en primicia El Decamerón (Il Decameron), de Pasolini, y Un soplo en el corazón (Le souffle au coeur), de Louis Malle, todas ellas de 1971 (Spector, 2017).

Si pensamos en las características de esta edición del festival, que no estaba dedicado precisamente al género documental, ni tenía tampoco un sesgo político marcado, lo que Cukor pudo encontrar en Canciones fue probablemente una película actual, innovadora, entretenida y de interés internacional. Algo que probablemente estaba también en la mente de su productor, Julio López Pérez-Tabernero, cuando decidió enviarla al Festival Internacional de Cine de San Sebastián, en vez de al de Valladolid, como estaba previsto todavía en abril de 1971 (Pastor Martín, 2004: 293).

A diferencia de las posteriores Caudillo y Queridisimos verdugos, Canciones para después de una guerra no se realizó de forma clandestina, sino pensando en un lanzamiento comercial de largo alcance y aceptando por ello, muy a pesar de Patino, las modificaciones que les impuso la comisión de censura (Pastor Martín, 2004: 292294). Ya durante su proceso de elaboración, el equipo había tenido mucho cuidado. Como legalmente era preceptivo un guion previo y detallado - que no había-, para que se concediera el permiso de rodaje, las autoridades, de acuerdo con el informe citado de Arroyo Stephens, permitieron condicionalmente el acceso a los archivos del No-Do y de la Filmoteca Nacional para utilizar sus fondos. Argumenta Stephens:

Dada la inseguridad del procedimiento, los productores consiguieron de la Dirección General, así como de No-Do y de Filmoteca Nacional, que cualificados representantes de estos organismos (Sr. Ada, secretario General de No-Do y Sr. Pinilla, de la Dirección General de Cinematografía) asesoraran oficiosamente, a título particular sobre la obra realizada en su proceso de elaboración y antes de obtener la copia definitiva, lo cual hicieron favorablemente con gran satisfacción de todos y la mejor voluntad de adaptar los reglamentos a la realidad. 
Según José Luis García Sánchez, en una crónica inédita que citaré más de una vez, titulada Artesanía en el cinema, durante este proceso de elaboración se hicieron algunas proyecciones provisionales: tras la última de ellas, a falta de algunos materiales y de terminar de legalizar el proyecto, en octubre de 1970, los asistentes, cuyos nombres no da, le "explican a Julio que va a ganar mucho dinero" (García Sánchez, 1970: 17).

Tras las modificaciones exigidas por la censura, la concesión de la categoría de Interés Especial, y su estreno previsto en el Festival de San Sebastián, aparentemente Canciones para después de una guerra estaba llamada a tener una carrera no solo nacional, sino quizás también internacional, como sugiere el interés del Filmex, que fue truncada por su prohibición, su incautación y su inexportabilidad. Su estreno tardío, en el contexto de la Transición, la condenó a ser un fenómeno local. A pesar de su buena acogida en festivales internacionales tras 1976, el interés internacional hacia productos como este, y también hacia lo que ocurría en España, había mutado.

Es difícil imaginar el interés internacional que Canciones para después de una guerra hubiera podido suscitar en 1971. Debemos conformarnos al menos con recontextualizar la película más allá de las fronteras españolas, algo que en España han intentado Casimiro Torreiro, relacionándola con los posteriores filmes de compilación Hermano, ¿puedes darme diez centavos? (Brother: Can you Spare a Dime?, 1975), de Philip Mora, o La guerre d'un seul homme (1981), de Edgardo Cozarinsky (Torreiro, 1997: 696) y Antonio Weinrichter (2008, 38-41) con trabajos previos de Emile de Antonio y con Le chagrin et la pitié (1969), de Marcel Ophuls, con la que comparte "una idea global -la recuperación de una memoria histórica negada- y, parcialmente, el método -la utilización de elementos de la cultura popular-" (Weinrichter, 2008: 38).

Nora M. Alter, que no menciona a Martín Patino en su libro sobre la evolución del cine-ensayo (Alter, 2017), plantea que su desarrollo en la Europa de la segunda posguerra mundial tiene, en una primera fase que iría hasta 1961, una marcada voluntad dar testimonio de una actualidad en proceso de transformación y "archivarla"; un segundo momento se extendería desde los sesenta hasta los noventa, en el que esta modalidad iría adquiriendo autoconciencia y, trabajando cada vez más -en soporte cinematográfico-, con materiales preexistentes, muchas veces de archivo, los reelabora de forma crítica. Algunos de los primeros ejemplos de esta segunda fase serían Brutalität in Stein (Kluge, 1961), La rabbia (Pasolini, 1963) y, más adelante, Loin de Vietnam (Lelouch, Godard, Varda, Marker, Ivens, Klein, 1967), y Unerlösschbares Feuer (Faroki, 1969). Pero hay que tener en cuenta también la contribución latinoamericana en la renovación de las estrategias comunicativas audiovisuales recurriendo a la reutilización de materiales preexistentes, una de cuyas muestras más potentes fue La hora de los hornos (Solanas y Getino, 1968). Como Alter recuerda, Italia fue, durante los sesenta, un nudo que relacionó el Tercer Cine latinoamericano con Europa (Alter, 2017: 249).

Basilio Martín Patino estuvo en la III Mostra Internazionale del Nuovo Cinema, de Pesaro, 1967, con ocasión de la presentación allí de Nueve cartas a Berta, premiada en San Sebastián en 1966. Fue invitado de nuevo a Italia, esta vez al Festival de Venecia, en 1969, para presentar Del amor y otras soledades, donde la película tuvo un recibimiento crítico poco cálido. En aquella edición, La primera carga al machete, del cubano Manuel Octavio Gómez, con su mezcla de elementos de ficción y técnicas de cine-encuesta, con las canciones de Pablo Milanés que comentan los 
hechos, tuvo una excelente acogida de público, y recibió una Medalla de Oro -aquel año no se repartieron los premios del Festival por cuestiones políticas-, además del Premio Luis Buñuel de la Crítica Española en Venecia. En el Festival de Venecia de 1969, caracterizado, según Cavallaro (1969, p. 79) por el canibalismo, el sexualismo y el alegorismo, "América Latina ha sido la vencedora moral", ejemplo de "discursos consistentes llenos de pasión y fuerza, cuyo ímpetu se resuelve también en una resuelta búsqueda expresiva y con una auténtica determinación de romper los esquemas del lenguaje" (Cavallaro, 1969, p. 75).

En este punto hay que recordar que, antes de que el impacto del Tercer Cine en Pesaro y en Venecia impulsara su reconocimiento internacional, Basilio Martín Patino ya había tenido contacto con algunas de sus obras. En el Certamen Internacional de Cine Documental y Cortometraje de Bilbao de 1966, donde fue miembro del jurado, fueron premiadas, entre otras, Now (Santiago Álvarez, 1965), película cubana que, sobre una canción que jazzea un conocido tema musical judío, combina imágenes documentales y fotografías de reportaje ajenos sobre la represión del movimiento por los derechos civiles de la población negra en Estados Unidos. También recibió allí un premio Electro-Shock (Patricio Guzmán, 1966), similar a la anterior en muchos aspectos técnicos y temáticos (Ortega Gálvez, 2018: 42).

No se puede afirmar que las rupturas que suponen algunos ejemplos del Tercer Cine fuese lo único que influyera en la decisión de hacer una película como Canciones para después de una guerra: hay que tener también en cuenta la experimentación en el propio contexto del documental español de la década -Javier Aguirre, Fernández Santos, la segunda cadena de Televisión Española desde 1968, e incluso el propio No-Do-. Sin olvidar la experiencia previa del propio Patino, que ya había practicado la combinación de imágenes de periódicos con las documentales en Torerillos 61 (1962). El conjunto pudo estimular planteamientos de montaje que Patino venía planteándose desde hacía tiempo: en un artículo suyo, de 1964, titulado "Hacia un nuevo concepto del montaje", finalizaba:

A falta de unas normas concretas, que serían la perdición estilística de cuantos se empeñasen en seguirlas a rajatabla, sugerir, obtener información, agitar los recursos del creador más que coaccionarle con academicismos, hacerle observar y experimentar todos los procedimientos de 'montar' según una representación más profunda del mundo: asociaciones, contrastes, contrapuntos sonoros, mecanismos de la atención, etc., para que cada cual pueda utilizarlo libremente según su necesidad. La más valiosa actitud ante el montaje es la del investigador ante la representación de la realidad o, lo que es lo mismo, ante la realidad misma. Y esta es una actitud de apertura sin límites ante el conocimiento del mundo que vivimos, de su arte, de su cultura, de todas las demás formas de expresión. (Martín Patino, 1964, 629)

La realidad, pues, se identificaba ya para Patino, en 1964, con sus formas de representación, y un lugar idóneo para realizar la aventura de conocerla era la mesa de montaje. 


\section{El proceso: de la documentación al descubrimiento}

Canciones para después de una guerra no partió de una idea clara, y su resultado final tiene mucho que ver con la relación que se fue estableciendo con los materiales que la construyen y con lo azaroso de su proceso de elaboración. Según Basilio Martín Patino (Pastor, 2004, p. 287), la idea de la película nació, a finales de 1969, durante un viaje en coche en el que la escritora Carmen Martín Gaite iba cantando canciones de Concha Piquer. Es posible, aunque quizás se trate de una versión algo incompleta del origen del proyecto. José Luis García Sánchez, en el texto inédito ya citado, Artesanía en el cinema, que es una crónica de la elaboración de la película -desde noviembre de 1969 hasta diciembre de 1970-, escribe:

Primeros días de noviembre. Julio Pérez Tabernero quiere debutar como productor de cine contratando a Patino. Dos 'mecenas' y la cosa se pone en marcha. Se contrata a un equipo de tres guionistas: el propio Patino, Alfredo Mañas y el que suscribe. Ya hay una línea bastante clara de lo que se va a hacer: una especie de reconstrucción histórica de la posguerra española a través de las canciones que en su día fueron más populares o más significativas. (García Sánchez, 1970, p. 1)

García Sánchez me aseguró, en conversación telefónica mantenida el veinte de junio de 2018, que en la base del proyecto estuvo la publicación, en la revista Triunfo, entre septiembre y octubre de 1969, de la serie de artículos de Manuel Vázquez Montalbán titulada Crónica sentimental de España, en la que las canciones populares funcionan como hilo conductor para radiografiar la España de la posguerra. $\mathrm{Su}$ impacto pudo convencer a Pérez-Tabernero de la viabilidad de un proyecto sustentado en canciones pertenecientes a la memoria "sentimental" de los españoles.

Según la crónica de García Sánchez, el equipo se puso a trabajar compartiendo recuerdos, haciendo fichas de temas a investigar y buscando materiales: discos, noticias, fotografías de actualidades, deporte y modas en revistas y periódicos del pasado. Había una única cosa clara: la película debía ser en color. En enero de 1970, todavía no se sabía si iba a ser argumental (García Sánchez, 1970: 4), y mientras tanto se seguía reuniendo documentación. Especialmente difícil era encontrar, al inicio, lo básico, el material sonoro, las canciones, comprando discos en rastros, buscándolas en los archivos no catalogados de Radio Madrid, de la Discoteca Nacional...

De la crónica de García Sánchez se desprende que, si podía haber algún tipo de argumento narrativo, guionizable, debía estar relacionado con una documentación exhaustiva. Para obtener un permiso de rodaje, era preceptivo un guion. Pero eso no podía hacerse porque no estaba claro todavía si iba a haber algo de ficción. No se descartaba rodar en aquellos casinos que habían sido y eran todavía lugares de reunión, o contar con actuaciones actuales de viejas estrellas de la canción popular. Mientras tanto, se acumulaban grabaciones, fotos de prensa, titulares de periódicos, fotografías familiares, cómics - como se decía entonces, tebeos-. En febrero de 1970, ocurre algo importante. Dice García Sánchez (1970: 5-6):

Nos dan un permiso - muy especial, naturalmente- para visionar los documentales rodados en 1940, 41 y 42 por el Departamento Nacional de Propaganda. Y es ahí donde encontramos el arranque de la película: unas imágenes con la liberación de Madrid; la gente cantando por la calle; las primeras ayudas de Auxilio Social; 
los niños repatriados... No cabe duda: eso tiene que ser el arranque de la película nuestra.

Tenemos un material realmente importante: las revistas semanales de los primeros años. Fotos, especialmente, es como un análisis de las cuestiones que entonces más afectaban a los españoles. Vértice, Signal, Radiocinema, Flechas y Pelayos, La Codorniz, Marca ... allí está, de una manera o de otra, nuestra historia durante una década. Y vemos claro que hay que olvidar ante esta realidad los planteamientos argumentales que nos hacíamos hasta hoy.

Es, pues, la acumulación de materiales visuales y sonoros procedentes de los años cuarenta, lo que elimina cualquier posibilidad de introducir una ficción y termina poniendo una frontera cronológica a la película, que al principio no tenía: "El volumen que va tomando el trabajo nos inclina a limitar nuestro tiempo. No vamos a llegar hasta 1970. Dejaremos el final hacia 1953 o 1954, con la llegada de la ayuda americana, con la vuelta del Semíramis" (García Sánchez, 1970: 6).

Mientras se filma y se contratipa, se fotografía, se accede a CINESCO y a No-Do y se siguen encontrando grabaciones, en julio de 1970 todavía no se ha conseguido el preceptivo permiso de rodaje. La razón es que sigue sin haber guion.

Para justificar esa carencia, Pérez-Tabernero envía a la Administración una "Memoria para el proyecto de realización de Canciones para después de una guerra (título provisional)". En este documento, conservado en la caja 36/5045 del Archivo General de la Administración, con toda probabilidad escrito en su mayor parte por Martín Patino, se explica que el proyecto consiste en "evocar, mediante imágenes visuales y sonoras los momentos de aquellas canciones, alegres, nostálgicas", "formando una antología". La fuerza y el arraigo de aquella canción española -sigo glosando casi literalmente- que quizás no se haya repetido, puede ser la base para un espectáculo cinematográfico de notable interés artístico y ser a la vez solvente económicamente. Se trata de la "necesidad de experimentar un espectáculo cinematográfico nuevo", ante el "descrédito de formas manidas, rutinarias". Como en la novela, se dice en el escrito, crece el desprestigio ante una anécdota y un protagonista alejados de nuestro horizonte humano. "Parece -continúa- que al espectador actual le interesan menos las historias de una narración banal, y más un mundo de sensaciones, situaciones de conciencia, las asociaciones y relaciones que estimulan su personal experiencia vital". Se trata de una nueva concepción del arte -dice-que renuncia al argumento, ante el desinterés por los caracteres psicológicos, buscando una "diferente escritura o montaje", una mayor libertad en la construcción espacio-temporal. El cine -afirma- no puede hacerle una ridícula competencia a una televisión que lleva gratis y a casa las estructuras de la novela del siglo XIX.

En lo que atañe a la justificación básica del informe desde el punto de vista legal, es decir, que no se haya presentado un guion, se dice que hay una "dificultad metodológica para proyectar lo nuevo bajo la atadura de los viejos engranajes" que impide construir un guion al estilo habitual. Habría que tener capacidad profética para saber lo que puede salir del trabajo que se está realizando, porque no se trata de adaptar el argumento de las canciones, de reproducir esos argumentos con personajes. Ya disponen, se afirma, de cuatrocientas grabaciones, de las que habrá que seleccionar quince, veinte, veinticinco. Es necesario seguir buscando imágenes, porque esta selección "está condicionada a la existencia de ese material visual idóneo, debidamente expresivo". Se trata de un proceso en el que cada canción exige imágenes, igual que 
"las imágenes que vamos encontrando condicionan la elección de las canciones", luego, hay que "conseguir que cada una quede en su sitio y su compás". En cuanto al rodaje con localizaciones, se prevé como complemento, buscando conseguir con él puntos de apoyo, contrapuntos, prolongación: es decir, estaría supeditado a una investigación de montaje audiovisual impredecible. Sobre la relación entre música e imágenes, se continúa hablando de "misteriosas afinidades":

Y estas extrañas imágenes con impacto nos han surgido en cualquier inesperada escena de una película, quizás mediocre, en el momento menos enfático de un documental insólito, donde de pronto cruza por la pantalla un peinado o un rostro o un objeto escondido y necesitado solo de ser realzado con otros elementos, en otra situación.

La película, se afirma, está "pensada en color, virando el viejo celuloide que se utilice de archivo". Está también previsto realizar entrevistas a los más prestigiosos cantantes de entonces, y rodar en:

casinos viejos y entrañables de provincia, comercios, rincones, vestigio de aquellas no muy lejanas y tan superadas formas de ser. (...) La valoración de las cosas insignificantes, los descoloridos anuncios, las escondidas fotos familiares, todo ese pequeño mundo objetual que al ser llevado a la pantalla cobra dimensiones nuevas, insólitas, casi agresivas ante nuestra rutinaria forma de observar el alrededor.

Termina el informe-alegato, afirmando que la película solo resultará coherente vista en su totalidad, y que se tratará de algo más que de un "producto prefabricado": de un "cine personal, sincero, hoy día raramente posible".

Como se sabe, la película pudo terminarse, ser presentada a censura, modificada a requerimiento de la comisión, y finalmente premiada con la categoría de Especial Interés Cinematográfico, antes de la agria y desmesurada polémica que terminó con su prohibición.

Canciones para después de una guerra es el resultado de un proceso en parte azaroso, en el que los materiales que se buscaban para documentar un proyecto terminan convirtiéndose en el material básico de un film de montaje, visto desde hoy, un auténtico film-ensayo, a mi parecer en la vanguardia internacional de su momento de realización: como descubrimiento en un proceso, y no como resultado de una idea preconcebida; como obra abierta, crítica, pero no didáctica; como espectáculo nuevo para sala cinematográfica; como alternativa a la televisión, adoptando sin embargo recursos aprendidos en la publicidad televisiva, en la que había trabajado también Basilio Martín Patino. El informe no culpabiliza a una televisión en la que como ya se dijo, sobre todo en la segunda cadena o UHF, se está produciendo una relativa experimentación: más bien justifica el proyecto como una nueva forma de espectáculo cinematográfico.

\section{Imágenes visuales y sonoras para un espectáculo poético y crítico}

Había una voluntad compartida por todo el equipo de realizar una obra que, por una parte, tuviera la calidad exigible para ser proyectada en condiciones óptimas, y por 
otra, que fuera capaz de llegar a cualquier tipo de público. En cuanto a lo segundo, era importante encontrar un equilibrio "entre el rigor que nos van a pedir los espectadores que vivieron los años cuarenta y el ritmo cinematográfico que exigen los espectadores de los setenta" (García Sánchez, 1970: 11). Por otra parte, y también en relación con la necesidad de dar vida nueva a materiales visuales antiguos, había que "hacer algo para evitar el virado convencional". En cuanto a lo primero, el problema era el de compatibilizar formatos, forzar el sonido óptico, etc. (García Sánchez, 1970: 10); toda una serie de problemas de laboratorio debidos a la necesidad de hacer visibles y audibles con la más alta calidad cinematográfica, esos "materiales de derribo, recogidos como podíamos", de los que hablaba Patino (2017: 112).

En esta circunstancia, de esos materiales importan más los contenidos que se les pueden extraer -“imágenes visuales y sonoras", los llamaba Patino en el informe citado-, poniéndolos en contacto, que reflexionar sobre su materialidad. Canciones no es una película que trate acerca de las relaciones entre fotografía, música, prensa, cine y pintura en calidad de medios distintos. Más bien lidia con la dificultad de ponerlos en contacto en un único soporte.

Uno de los retos técnicos de Canciones era el de traer al soporte cinematográfico estandarizado de más alta calidad materiales de la más variada procedencia. Por razones de esa calidad exigida, se desechó rápidamente trabajar con filmaciones en 16mm. (García Sánchez, 1970: 7); los filmes utilizables forzaron la relación de aspecto final de la película: "No hay forma de trabajar para conseguir que la película quede definitivamente con 'caché' panorámico. Hay que desanamorfizar algunas películas, reducir encuadres, forzar el sonido óptico en laboratorios para salvar no sé qué..." (García Sánchez, 1970: 10).

A pesar de todo, se consiguió realizar un producto planificado para atraer espectadores a la sala cinematográfica. Además del ritmo y la velocidad, estaba el color, algo que desde el principio se vio como imprescindible. Quizás no solo por la tendencia a su uso cada vez mayor, sino para sumarlo a una "escritura", un "montaje" distinto del de las estructuras narrativas causales "decimonónicas" que ofrecía entonces una televisión que se veía mayoritariamente en blanco y negro. El uso del color en la película es constituyente del ritmo, de la calidad, y de la cualidad distintiva del producto. Para la película fue contratado, como parte del equipo, el pintor Alfredo Alcaín, que ya había colaborado previamente con Patino haciendo los carteles de sabor medieval para los títulos de los capítulos en los que se dividía Nueve cartas a Berta. En una conversación telefónica mantenida con él el diecinueve de junio de 2018, Alcaín me aseguraba que su participación en Canciones fue pequeña, limitándose, aparte de a realizar el cartel - cuyo grafismo escrito le dio ya el propio Basilio-, a realizar las imitaciones de la publicidad comercial para cines que se intercalan en la sección titulada Descanso -la mayoría a partir de fotos antiguas de prensa, aunque alguno "seguramente", me dijo, también inventado-, y a realizar algunos coloreados. Uno de ellos es, por ejemplo, el que va sobre las imágenes de la película Esta es mi vida (Román Viñoly Barreto, 1952), con la canción La hija de don Juan Alba, interpretada por Miguel de Molina. Pintaba a partir del primer fotograma de la secuencia, sobre una plantilla que se superponía luego al resto, de manera que la imagen y los colores se desincronizaban, generando un efecto "chapucero", casi cómico. Sin embargo, García Sánchez, en conversación telefónica del veinte de junio de 2018, me aseguraba que la participación de Alcaín fue importante para unificar el tratamiento colorístico de la película. 
Hay muchos virados en Canciones para después de una guerra - a verdes, anaranjados, amarillos, sepias que se contraponen con el blanco y negro y entre sí-. También hay algunas superposiciones de imágenes en color de objetos difuminados o de carácter abstracto. En una parte muy importante de los casos, el color no tiene aparentemente otra función que la de ser parte de la variación rítmica del conjunto, aunque también señale a veces situaciones cronológica o espacialmente separadas e incluso, contraponiendo rojos y azules, dote a algunos momentos de una intencionalidad política, como afirma Alberto Nahum (2008: 151), aunque esto no sea extrapolable al conjunto de la película.

Canciones para después de una guerra es un auténtico collage de materiales de distinta procedencia. El resultado, según Català (2001: 39-40), no consigue tanto llamar la atención sobre la materialidad de los componentes de la película, con sus respectivas cronologías, sus ataduras, como "documentar la textura misma de la memoria en su funcionamiento". El cine, entonces, parece el medio en el que es posible realizar una operación de pensamiento poco explorada.

En otro nivel de planteamiento, el de la intersección entre Media Culture y Media Economy (Müller, 2016), el proyecto presentado por el productor a las autoridades, como ya vimos, planteaba la película como directamente enfrentada a lo que entonces era la televisión, tanto en el nivel de la "escritura" como en el del espectáculo.

La radio aparece amalgamada con fotografías, noticiarios cinematográficos, números musicales, noticias de periódicos, publicidad gráfica, fotografías familiares, informes oficiales, cómic, en un todo que compone el grueso de este collage. La televisión, sin embargo, recibe un tratamiento distinto, con un fragmento único dedicado a ella. La canción en la que se engarza, interpretada por Lolita Garrido, es un tema de 1947 titulado La televisión pronto llegará: las imágenes hacen referencia a las nuevas relaciones que se establecen con Estados Unidos en el contexto de la Guerra Fría, la llegada de famosos actores y actrices norteamericanos a España, pruebas técnicas del nuevo medio, su aparataje tecnológico -cámaras, monitores-, todo ello entremezclado con rodajes en estudio de danzas populares españolas. En momentos en lo que no se oye a la cantante, pero sí la música, entra la voz en off de un joven -ya hemos oído antes otras voces en off, anónimas- que habla de cambios gracias a los pactos que se están estableciendo -en los cincuenta- con Estados Unidos, mientras sobre las imágenes monocromas se superpone a veces una reja difusa en color:

No hay remediación, absorción de las imágenes televisivas, como pudo hacerse incluso con los mensajes radiofónicos. La película se detiene antes de que la televisión aparezca efectivamente en España, en 1956. Este nuevo medio es visto como un ente extraño que llega, significativamente relacionado con las estrellas de Hollywood y los acuerdos con Estados Unidos, como algo globalizador, penetrador y transformador, contemplado a través de esa reja y en relación con esas reflexiones de una voz no atribuible al autor que aún marcan la distancia con el resto del mundo. ¿Anuncia la televisión la pérdida de la cultura popular que, a través de las canciones, ha atravesado el régimen del Nuevo Estado, y la ha comunicado con el pasado? Recordemos que sobre la canción Vengo del templo de Salomón se sucedían y superponían imágenes de actuaciones de la famosa cantante gitana Lola Flores con recortes de prensa y fotografías que indican su inmensa popularidad, y con imágenes procedentes de películas del período republicano, indicando una continuidad en la cultura popular que el régimen no solo no pudo romper, sino que terminó utilizando. Particularmente interesante es un encadenado de una actuación de baile de Lola Flo- 
res sobre imágenes de una coreografía de Morena Clara (Florián Rey, 1936), el gran éxito del cine español durante la República.

Desde este punto de vista, Canciones para después de una guerra despierta preguntas complementarias a aquellas en las que durante mucho tiempo se ha centrado la bibliografía, por causa de su prohibición y tardío estreno, es decir, las que atañen a la recuperación, en España, de la memoria histórica. A esas preguntas hoy podrían sumarse otras: ¿qué cualidades de la película pudieron interesar a Cuckor y Vidor para intentar programarla en Los Ángeles en 1971, al lado de Il Decameron, de Pasolini, de Le souffle au coeur, de Louis Malle y de The last picture show, de Bogdanovich?, ¿existen intentos internacionales, paralelos y contemporáneos de construir como espectáculo cinematográfico, es decir, no minoritario, obras que hoy vemos en otros soportes y dispositivos y que catalogamos como cine-ensayo?, ¿en qué medida la película proponía la posibilidad de un cine nacional y popular como línea de resistencia frente a la homologación cultural que parecía traer consigo la televisión?

\section{Conclusiones}

La importancia que atribuimos a una obra cambia con su contexto de recepción. Mi intención, en estas páginas, ha sido la de intentar recontextualizar Canciones para después de una guerra en un momento al que respondía directamente, que era el que va de 1969, año en el que empezó a gestarse, hasta 1971, en el que se dio por finalizada. La afirmación de Jorge Nieto Ferrando de que la película estira los límites de lo visible y lo decible hasta "quebrarlos y quedar fuera del posibilismo institucional" (Nieto Ferrando, 2006: 73), refiriéndose, evidentemente, a España y al régimen franquista, probablemente no hubiera podido pronunciarse con tanta contundencia, como hemos visto, ni en 1969, ni en 1971. Quizás el equipo confió ingenuamente en que los vínculos del productor Julio López Pérez-Tabernero con la familia de Franco y con la industria cinematográfica (Riambau y Torreiro 2008: 623-624), y la propia ambigüedad -nada acrítica, como ya se ha repetido insistentemente- del producto, debidamente corregido por la censura, en un momento de inestabilidad interna de la propia dictadura dividida en "familias", lo convertirían en un producto "posibilista". Quizá también se confió en que las relaciones internacionales de Pérez-Tabernero, que había trabajado en la televisión en Los Ángeles, podrían ayudar a dar visibilidad de la película en el extranjero, si esta emprendía su carrera a partir de un festival de categoría internacional, como el de San Sebastián, y en el nombre de Patino, cuyos dos largometrajes previos habían participado en festivales internacionales, y por eso se desechara la idea de su estreno en un festival como el de Valladolid, no de la misma categoría, y más abierto al estreno de películas arriesgadas para su difusión en el ámbito nacional.

Vuelvo entonces al título de este estudio, que habla de una película "en dos tiempos", que son dos contextos de recepción. La película estaba planteada desde el conocimiento de lo que se exhibía tanto en un contexto nacional como en el internacional: en ambos tenía mucho que decir en aquel momento, y en ambos hubiera podido abrir brechas y ser innovadoramente constructiva. Cuando finalmente se estrenó en 1976, en España fue un éxito vinculado a la situación política y a la recuperación de la memoria histórica, pero su carrera por festivales internacionales, a pesar de su buena acogida, no respondía ya a la misma actualidad, ni mediática, ni política para 
la que fue pensada antes y durante el proceso de elaboración. Los trabajos sobre material de archivo se habían multiplicado en Europa, mientras que la crítica de los medios de comunicación se había ido desplazando en Estados Unidos al ámbito de la institución artística, a través del vídeo. Una película como Canciones para después de una guerra, planteada con todas sus dificultades para conseguir la mejor calidad exigida desde los máximos estándares, como alternativa de "espectáculo cinematográfico" frente a la televisión, ya no era lo que respondía a las urgencias del momento. Se trataba de una película políticamente crítica, pero ambigua, y esa ambigüedad no atañía solo al ámbito español del momento, sino que se daba como ejercicio de libertad tanto del autor como del espectador ante cualquier discurso unívoco. Una película, finalmente, posicionada también frente a la televisión, que defiende el dispositivo cinematográfico frente a esta distanciándose de la narración convencional, poco tiene que hacer, internacionalmente, en 1976, en una economía de los media que estaba cambiando a pasos acelerados.

Pero además y quizá, sobre todo, la actualidad política de Canciones, desde el punto de vista del contexto internacional, se había transformado también drásticamente. A partir de 1976 y sobre todo 1977, cuando ya pudo verse también fuera de España, no era ya una obra que se refiriese, a través de su revisión de los años cuarenta, a una situación política -la dictadura- todavía presente. Ya no existía la dictadura. España estaba empezando a normalizar su existencia internacional. En este sentido era ya una obra del pasado. Su intento de conjugar reflexión y espectáculo había quedado también desfasado. Había asuntos más urgentes, no ya solo en el Tercer Mundo, sino en la misma Europa, como demuestra, por poner solo un ejemplo, Alemania en otoño (Deutschland im Herbst, VV.AA., 1977), sobre el terrorismo y la respuesta del Estado, que parecían exigir acercamientos estéticos muy diferentes, en los que la dimensión de juego y de fascinación estaba fuera de lugar. Los rescoldos del 68, con su dimensión lúdica, que todavía ardían en 1969, cuando se inició Canciones para después de una guerra, estaban siendo apagados por la gravedad que imponían los años de plomo. De este modo, durante años, la película ha quedado anclada a su importancia en un contexto exclusivamente nacional como es el de la Transición política a la democracia, a su función en la recuperación de la memoria histórica.

Habría que hablar, para Canciones, de un tercer tiempo, que es el de su recuperación, incluso podría decirse que el de su reivindicación en momentos más recientes: una obra, pues, no solo en dos tiempos, sino en tres, el último relacionado con nuevos contextos de recepción, paradójicamente no vinculados a su propuesta inicial como espectáculo poético-crítico para sala cinematográfica.

Hay varios factores que intervienen en ello: por una parte, la capacidad de Basilio Martín Patino para haber seguido trabajando e innovando en distintos soportes, medios e instituciones, manteniendo sin embargo una propuesta básica capaz de atravesar las distintas actualidades y urgencias que se han ido sucediendo. Puede escucharse en el número cero de La Nueva Ilustración Española, intento de publicación audiovisual periódica que pusieron en marcha Martín Patino y García Sánchez a través de Videoteca, S.A.:

El cine es la experiencia de la representación simultánea de tiempos diferentes y de espacios separados. La bidimensionalidad del tiempo, que juega con parcelas de mundos distantes y nos afirma en la conciencia de la contemporaneidad. Un presente que adquiere realidad al constatar que existimos, porque nos permite 
revivir lo ya sucedido, como una confirmación de la caducidad irremediable de nuestra propia historia. (Pérez Millán, 2002: 211)

Una posición que encontramos ya en un trabajo temprano, de carácter teórico, como es su artículo Hacia un nuevo concepto de montaje (Film Ideal, 1964), donde afirmaba:

Montaje es, pues, todo aquello que coordina la representación espacial del tiempo. (...) Por el montaje particularmente, utilizando unos procedimientos $\mathrm{u}$ otros, puede el hombre de cine penetrar en los aspectos más complicados de la vida y desmontar su engranaje, sus relaciones y causas ocultas. O su ininteligibilidad, si considera el mundo no inteligible, a condición de que considere la inteligibilidad cinematográfica como base gnoseológica de la obra de arte. (...) Y esta es una actitud de apertura sin límites ante el conocimiento del mundo que vivimos, de su arte, de su cultura, de todas las demás formas de expresión. (Patino, 1964: 628-629)

Llevando este convencimiento a sus trabajos en video, a los cinematográficos, a la televisión, a los espacios museísticos, a exposiciones nacionales e internacionales, lo ha mantenido vivo y ha invitado a que su obra anterior haya podido ser revisada desde nuevas perspectivas, así como desde planteamientos teóricos, como por ejemplo el del cine-ensayo, o los intermediales, que permiten redescubrir en ella nuevas dimensiones.

Esta revisión, sin embargo, no hubiera sido tan sencilla si esa obra anterior, entre la que hay que incluir Canciones, se hubiera quedado atrapada en las Filmotecas. Las copias que pudieron hacerse en VHS o en Beta tras su pase en TVE, pero sobre todo su edición en DVD en 2008 -junto con buena parte de la obra de Patino, hoy descatalogada-, han permitido ver de nuevo Canciones para después de una guerra en mejores condiciones de manipulación, incluso, que las que tuvieron los censores.

Es entonces, en este tercer tiempo que ha tenido Canciones, cuando entran en juego nuevas posibilidades tecnológicas, con una mayor distancia con respecto al momento histórico de su estreno tardío, con un conocimiento de la obra global de su autor, y con nuevos instrumentos críticos y teóricos, cuando pueden realizarse acercamientos a la película que la rescaten definitivamente de su prohibición y la traigan a otra actualidad, que permitan ver qué "otra cosa" era, pudo ser y quizá pueda ser.

Los intentos de recontextualizarla relacionándola con el cine-ensayo o con prácticas similares, por parte de Torreiro, Weinrichter, o Català, son a la vez ejemplares y sintomáticas de un nuevo contexto de recepción que ya no es solo nacional, sino potencialmente global. Ana Martín Morán (2008), en un espléndido estudio sobre Canciones para después de una guerra, desarrolla, desde una perspectiva que se inscribe en los estudios culturales y de género, el modo en que Martín Patino recicla la cultura popular del pasado mediante técnicas aprendidas en la publicidad, devolviendo a las Canciones su cualidad irónica, subversiva, su capacidad de aludir a las contradicciones de su momento. También los trabajos de Aurora Fernández Polanco -2008 y 2011-, aunque no dedicados específicamente a esta película, aportan una visión particularmente interesante, en la medida en la que confirman esta ampliación de la perspectiva sobre la obra de Martín Patino. Ayudándose de Gilles Deleuze, Walter Benjamin y sobre todo de Georges Didi-Huberman, Fernández Polanco plantea la obra de Basilio Martín Patino como la construcción de una "imagen cristal" 
en la que lo actual y lo virtual, reflejándose mutuamente, tienen en cuenta el tiempo, la historia, no como disciplina académica, sino como intento de relación entre el presente y el pasado. La relación entre actualidad, virtualidad y pasado componen un pensamiento sobre la historia que no está sin embargo despegado del tiempo en el que se interactúa con unos materiales y en unas circunstancias políticas determinadas. Si en Canciones para después de una guerra las fotografías, por ejemplo, forman parte del collage general, en Madrid (1987), como explica Fernández Polanco, hay una reflexión acerca de la diferencia entre fotografía o imagen detenida e imagen móvil que allí todavía no se daba.

A través sobre todo de Walter Benjamin, Fernández Polanco (2011) insiste en los conceptos de fascinación y juego en la obra de Patino que a mí me parecen centrales: Benjamin estaba interesado en los juguetes en general; Patino, particularmente en los juguetes ópticos y en la capacidad para fascinar de sus imágenes. Revisitar la infancia, época de juego, de inconsciencia, con la conciencia de la edad adulta, es lo que hicieron Patino y el resto del equipo que construyó Canciones, retratándose al final, en los títulos de crédito de la película, con sus fotografías de Primera Comunión.

En su discurso de investidura como Doctor Honoris Causa de la Universidad de Salamanca, Patino citó Homo ludens, que Johan Huizinga publicó en 1938. En la base de la argumentación de Huizinga está el rechazo a considerar el ser humano solo como homo sapiens y homo faber. También es homo ludens. Jugar de verdad, decía allí Huizinga -sin olvidar el componente agónico, de competición, de todo juego-, es convertirse en niño (Huizinga, 2000: 252), pero el juego tiene un componente orgánico que lo relaciona con la estructura social (Huizinga, 2000: 250). El juego tiene algo de esa "apertura sin límites" que Patino atribuía al montaje en su escrito de 1964. Huizinga oponía el juego a la seriedad cultural de su mundo contemporáneo, que sigue siendo el nuestro, a pesar de la Segunda Guerra Mundial, cuyo final pudo hacer pensar que todo cambiaría, a pesar del 68, su vinculación con el juego y sus inmediatas secuelas, entre las que quizá haya que recontextualizar también la Canciones para después de una guerra de 1969-1971, que empezó como un ejercicio lúdico y fue encontrando, sin dejar de serlo, su función orgánica consciente en la estructura social a medida que se realizaba.

"Que la película fuera prohibida creo que forma parte del juego", dijo una vez Basilio Martín Patino (Bellido, 1996: 200).

\section{Bibliografía}

Alter, N. M. (2017). The Essay Film After Fact and Fiction. Nueva York: Columbia University Press.

Benet, V. (2012). El cine español. Una historia cultural. Barcelona: Paidós.

Berthier, N. (2011). "De Franco, ese hombre, a Caudillo: la figura de Franco, un reto para la Transición”, en Manuel Palacio (Ed.), El cine y la transición política en España (19751982). Madrid: Biblioteca Nueva.

Català, J. Ma . (2001). "La crisis de la realidad en el documental español contemporáneo", en Josep $\mathrm{M}^{\mathrm{a}}$ Català, Josetxo Cerdán, Casimiro Torreiro, Imagen, memoria y fascinación. Notas sobre el documental en España. Madrid/Málaga: Ocho y Medio, IV Festival de Cine Español De Málaga, pp. 27-44. 
Cavallaro G.G. (1969). "Amplessi ambigui tra massa ed elite". Il dramma, nº 12.

Fernández Polanco, A. (2008). "Basilio Martín Patino y la imagen-cristal”, en VV.AA.: Espejos en la niebla. Madrid: Círculo de Bellas Artes, pp. 45-80.

Fernández Polanco, A. (2011). "Le cinéma devant l'histoire. Voir Basilio Martín Patino avec Georges Didi-Huberman”, en T. Davila et P. Sauvanet (eds.) Devant les images. Penser l'art et l'histoire avec Georges Didi-Huberman. París: Les presses du réel.

García Sánchez, J. L. (1970). “Artesanía en el cinema”. Inédito. Archivo General de la Administración, caja 36/05046.

Hopewell, J. (1989). El cine español después de Franco. Madrid: Ediciones El Arquero.

Huizinga, J. (2000). Homo Ludens. Madrid: Alianza Editorial.

Martín Morán, A. (2008). "En la boca del lobo... que canta. La cultura popular y la reconstrucción de la identidad nacional en Canciones para después de una guerra", en Carlos Martín (Coord.): En esto consistían los paraísos. Aproximaciones a Basilio Martín Patino. Granada: Centro José Guerrero, pp. 52-75.

Martín Patino, B. (1964). "Hacia un nuevo concepto del montaje”, Film Ideal, n 152, Madrid, 17 de septiembre, pp. 621-629.

Martín Patino, B. (2017). "Sobre Canciones para después de una guerra", en VVAA, Basilio Martín Patino. Madrid. Rompeolas de todas las Españas. Madrid: La Fábrica, pp. 109115)

Müller, J. (2016). "And where do we go next? Some Current Fields of Research in Media Culture and Media Economy -Illustrated by the Example of Michael Jackson's Trhiller", Media, Film and Communication, Working Paper Series, University of Otago, recuperado de: https://www.otago.ac.nz/mfco/otago637063.pdf

Nahum García Martínez, A. (2008). El cine de no-ficción de Basilio Martín Patino. Madrid: Ediciones Internacionales Universitarias.

Nieto Ferrando, J. (2006). Posibilismos, memorias y fraudes. El cine de Basilio Martín Patino. Valencia: Ediciones de la Filmoteca, Filmoteca de la Generalitat Valenciana.

Ortega Gálvez, M. L. (2018). “Transnacionalidad y documental a través del Atlántico: perspectivas desde los cines en español", TSN. Transatlantic Studies Network: Revista de Estudios Internacionales, Vol. 3, $\mathrm{n}^{\mathrm{o}}$ 5, enero-julio, pp. 37-46.

Pastor Martín, E. (2004). "El nudo gordiano de Canciones para después de una guerra", Cuadernos de la Academia, $\mathrm{n}^{\circ}$ 13-14, El cine español durante la Transición democrática (1974-1983), actas del IX Congreso de la Asociación Española de Historiadores del Cine, pp. 285-304.

Pérez Millán, J. A. (2002). La memoria de los sentimientos. Basilio Martín Patino y su obra audiovisual. Valladolid: 47 Semana Internacional de Cine de Valladolid.

Pérez Perucha, J.; Ponce, Vicente. (2011). "Algunas instrucciones para evitar naufragios metodológicos y rastrear la Transición democrática en el cine español”, en Palacio, Manuel (ed.), El cine y la transición política en España (1975-1982). Madrid: Biblioteca Nueva, pp. 223-268.

Spector, L. (2017). "The first Filmex and my first film festival”, en Bayflicks. The Spector's guide to everything cinema in the San Francisco Bay Area, 16 de mayo, recuperado de: https://bayflicks.net/2017/05/16/the-first-filmex-and-my-first-film-festival/

Riambau, E.; Torreiro, C. (2008). Productores en el cine español. Estado, dependencias y mercado. Madrid: Cátedra.

Torreiro, C. (1997). "Canciones para después de una guerra”, en Julio Pérez Perucha (Ed.), Antología crítica del cine español (1906-1995). Madrid: Cátedra, pp. 695-697. 
Trenzado Romero, M. (1999). Cultura de masas y cambio político: El cine español de la transición. Madrid: Centro de Investigaciones Sociológicas.

Vélez Jiménez, P. (2014). “Todo memoria. La trilogía de Basilio Martín Patino”, en Navajas, Carlos e Iturriaga, Diego (Coords.): España en democracia. Actas del IV Congreso de Historia de nuestro tiempo, pp. 259-269.

Weinrichter, A. (2008). "La seducción de la moviola. El síndrome del montaje en el cine de Basilio Martín Patino", en Carlos Martín (Coord.): En esto consistían los paraísos. Aproximaciones a Basilio Martín Patino. Granada: Centro José Guerrero, pp. 34-51) 